\title{
The Association Between Resistivity Index (IR) and the sFlt-1 and PIGF Values in Pregnant Women With Risk of Preeclampsia
}

\author{
GEORGE TOTH ${ }^{1 \#}$, MARIUS CRAINA ${ }^{1}$, LAVINIA STELEA ${ }^{1 \#,}$ COSMIN CITU $^{1}$, RADU NEAMTU $^{1}$, ATILA FOGOROSSY ${ }^{1}$, \\ RADU DUMITRU MOLERIU2*, RAZVAN BARDAN ${ }^{3 *}$, IZABELLA PETRE ${ }^{1 *}$, RAZVAN SUSAN ${ }^{1}$, ADELINA CHEVERESAN ${ }^{1}$, \\ NICOLAE SUCIU 4 \\ ${ }^{1}$ Victor Babes University of Medicine and Pharmacy, Department XII, Discipline of Obstetrics and Gynecology, 2 Eftimie Murgu \\ Sq 300041, Timisoara, Romania \\ ${ }^{2}$ West University of Timisoara, Faculty of Mathematics and Computer Science, Department of Mathematics, ROMANIA \\ ${ }^{3}$ Victor Babes University of Medicine and Pharmacy, Department XV, Discipline of Urology, 2 Eftimie Murgu Sq 300041, Timisoara, \\ Romania \\ ${ }^{4}$ Carol Davila University of Medicine and Pharmacy, Department of Obstetrics and Gynecology, Alfred Rusescu Institute for \\ Mother and Child Care, Bucharest, Romania
}

\begin{abstract}
Worldwide, 5-8\% of pregnant women are diagnosed with preeclampsia. This disease increases the morbidity and mortality of the fetus and pregnant woman, especially in developing countries. Preeclampsia is characterized by systolic blood pressure $>140 \mathrm{mmHg}$ or diastolic blood pressure $>90 \mathrm{mmHg}$ as measured twice, and $24 \mathrm{~h}$ proteinuria $\geq 0.3 \mathrm{~g}$, after 20 weeks of gestation. The cause of preeclampsia is still incompletely elucidated. Numerous studies have suggested to modernize the definition of preeclampsia by incorporating key biomarkers of either placental or vascular origins, including placental growth factor (PIGF) and antiangiogenic factors such as tyrosine kinase-1 (sFlt-1) in the diagnosis of preeclampsia and the risk of occurrence of the disease in the second trimester of pregnancy [1-5]. We studied a group of 50 patients with a 21-week pregnancy diagnosis, we calculated the ratio between sFIt-1 and PIGF and we tested to see if there was an association between this ratio and the resistivity index (IR) of the uterine artery using the artery Doppler ultrasound. The PIGF level in our group was decreased in women who developed preeclampsia compared to the control group where this problem did notoccur. Doppler ultrasound examination during the second trimester of pregnancy may provide extra data for prediction of preeclampsia. Although much of pathophysiology of preeclampsia has been explained, the exact etiology of this disorder remains unclear. It is certain that before the clinical signs of preeclampsia are detectable, there is an imbalance between proangiogenic and anti-angiogenic factors.
\end{abstract}

Keywords: placental growth factor, tyrosine kinase-1, preeclampsia, uterine artery resistivity index

Over the last decade, the definition of preeclampsia was revisited as the mechanisms underlying the disease were dramatically evolved. [6-8]. The exact pathophysiology of preeclampsia remains undefined. There are many studies that support the hypothesis that the occurrence of this pathology would be due to an insufficient placental perfusion that would result from an abnormal remodeling of the maternal spiral arteries [9-13].

In preeclampsia, the maternal placental growth factor (PIGF) is decreased, while the serum level of tyrosine kinase-1 (sFlt-1) is increased.

A PIGF's antagonist, the soluble vascular endothelial growth factor receptor 1 (sFlt-1) causes vasoconstriction and endothelial lesions that can lead to intrauterine growth restriction and preeclampsia. High sFIt-1/PIGF ratio is associated with an increased risk of preeclampsia and can be a better predictor of preeclampsia than any other biomarker [14-16]. Angiogenic and anti-angiogenic factors have been implicated in the pathophysiology of preeclampsia. In general, the t-1/PIGF ratio appears to show better performance than single markers $[17,18]$. Some studies support the theory that starting low-dose aspirin before 16 weeks of gestation would benefit pregnancy, reducing the risk of preeclampsia $[19,20]$.

\section{Experimental part}

Material and methods

For this study we gathered information from 50 patients. We have a homogenous sample: all the patients are pregnant in week 21 and they all were submitted to the same medical tests. The database was collected using an Excel file. The statistical analysis was run using the SPSS program and for the charts and tables we used the Microsoft Excel program. In the first part of our study we tested the distribution of the data. Further on, we wanted to see if there are any differences between the body mass index (BMI) before pregnancy and now (in week 21) and the $\mathrm{BMI}$ in patients with or without preeclampsia. We calculated a report between the sFIt-1 and PIGF values and we tested to see if there is an association between this report and the resistivity index (IR). As well, we have information about the patients age, environment, the Doppler values in week 21 and if they are smokers or non - smokers. For the statistical tests we applied the MannWhitney test and for the association of values we calculated the Pearson coefficient and we applied a regression model for this data. The significance level is considered $\alpha=0.05$. 


\section{Results and discussions}

In this study, as we mentioned before, we have tested 50 patients. For a better characterization of our sample we run some descriptive statistics on the numerical data (table 1) and we plotted the main results (fig. 1, 2). From our 50 patients, 19 patients (38\%) are non - smoker and 31 patients $(62 \%)$ are smokers.

Further on, for the statistical analysis, as we mentioned before, we tested to see if we have normal distribution in our data. For this, we applied the Kolmogorov - Smirnov normality test and we obtained that our data are not normally distributed $(p<0.05)$. So, using the Man -Whitney test we wanted to see if the differences observed in the BMI before pregnancy and now (week 21) can be considered significant. After applying the test we obtained $p=0.38>0.05$, so we can conclude that even if we have a higher BMI in week 21 this differences are not statistically significant. Another major classification is made behalf the presence / absence of preeclampsia. For all numerical variables which we tested in this classification we obtained significant differences only in the case of BMI and in the case of the sFlt-1 values $(P<0.05)$. So, we can say that the patients who developed preeclampsia have a significantly higher BMI and a significantly higher sFlt-1 value. The last statistical test was run to see if the smoking habit alone can influence the dynamics of the tested data. After applying the Mann - Whitney test on all numerical data (age, BMI before and now, Doppler, sFIt-1, PIGF, reportand IR) we obtained insignificant differences $(p>0.05)$ in all cases. So, the smoking habit alone can't be considered a trigger in this case.

In the last part of this study, we tested to see if we can find an association between the calculated report (the report was obtained by dividing the sFIt-1 values to the PIGF values) and the resistivity index (IR) and between the Doppler and the IR values, both obtained in week 21.

Table 1

WE CALCULATED THE CENTRAL TENDENCY AND DISPERSION INDICATORS FOR THE NUMERICAL DATA INCLUDED IN THE STUDY.

\begin{tabular}{|l|r|r|r|r|r|r|r|r|}
\hline Statistics & \multicolumn{1}{|c|}{ Age } & BM before & Actual BMI & $\begin{array}{r}\text { Doppler } \\
\text { 2l weeks }\end{array}$ & \multicolumn{1}{|c|}{ sFit-1 } & \multicolumn{1}{l}{ PIGF } & Report & IR \\
\hline Mean & 31.40 & 25.20 & 26.16 & 0.52 & 1526.57 & 174.75 & 11.92 & 0.8452 \\
\hline Standard Error & 0.67 & 0.76 & 0.80 & 0.02 & 84.60 & 17.09 & 1.10 & 0.01 \\
\hline Median & 32 & 23.81 & 24.45 & 0.52 & 1489 & 134.55 & 10.29 & 0.85 \\
\hline Mode & 29 & 23.53 & 21.09 & 0.43 & 1009 & 101 & & 0.85 \\
\hline Standard Deviation & 4.77 & 5.36 & 5.64 & 0.12 & 598.19 & 120.82 & 7.77 & 0.06 \\
\hline Sample Variance & 22.73 & 28.69 & 31.85 & 0.01 & 357831.93 & 14597.29 & 60.30 & 0.00 \\
\hline Kurtosis & -0.90 & 2.00 & 1.42 & -1.15 & -0.01 & 5.77 & 0.23 & -0.58 \\
\hline Skewness & -0.09 & 1.43 & 1.27 & 0.07 & 0.51 & 2.10 & 0.97 & 0.00 \\
\hline Range & 19 & 24.76 & 25.18 & 0.44 & 2411.10 & 648.8 & 30.63 & 0.2 \\
\hline Minimum & 22 & 18.37 & 19.43 & 0.34 & 486.90 & 36 & 2.48 & 0.75 \\
\hline Maximum & 41 & 43.13 & 44.62 & 0.78 & 2898.00 & 684.80 & 33.11 & 0.95 \\
\hline Sum & 1570 & 1259.79 & 1308.14 & 26.11 & 76328.30 & 8737.30 & 596.14 & 42.26 \\
\hline Count & 50 & 50 & 50 & 50 & 50 & 50 & 50 & 50 \\
\hline
\end{tabular}

The distribution of BMI before and during pregnancy

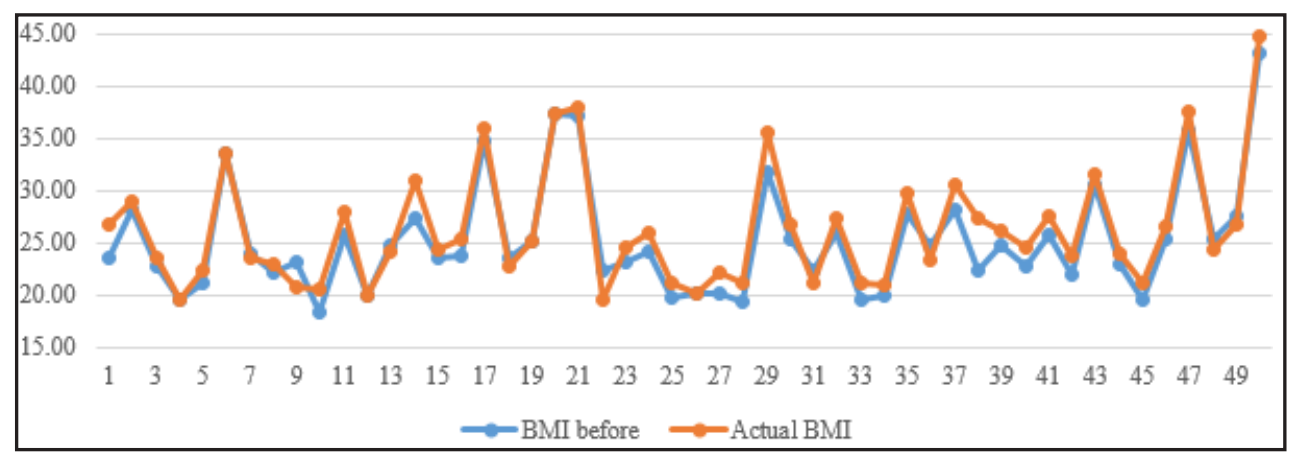

Fig. 1. The dynamics of the BMI before pregnancy and in week 21 .

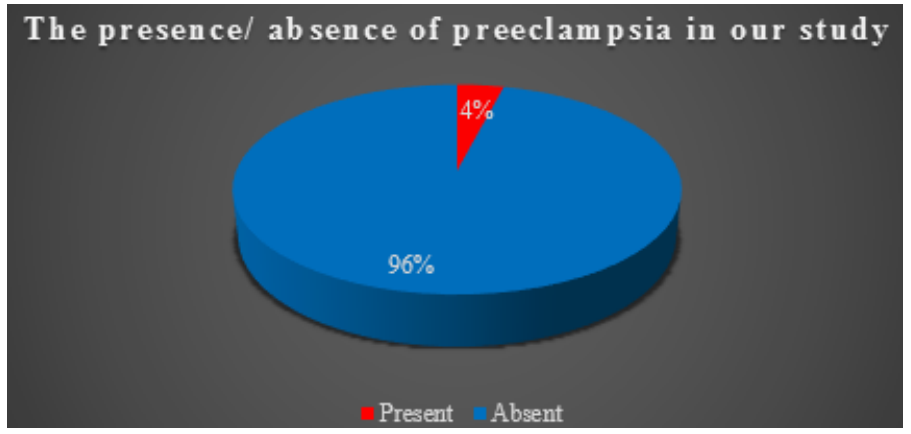

Fig.2 The presence/absence of preeclampsia, a major complication that can be seen during pregnancies. 

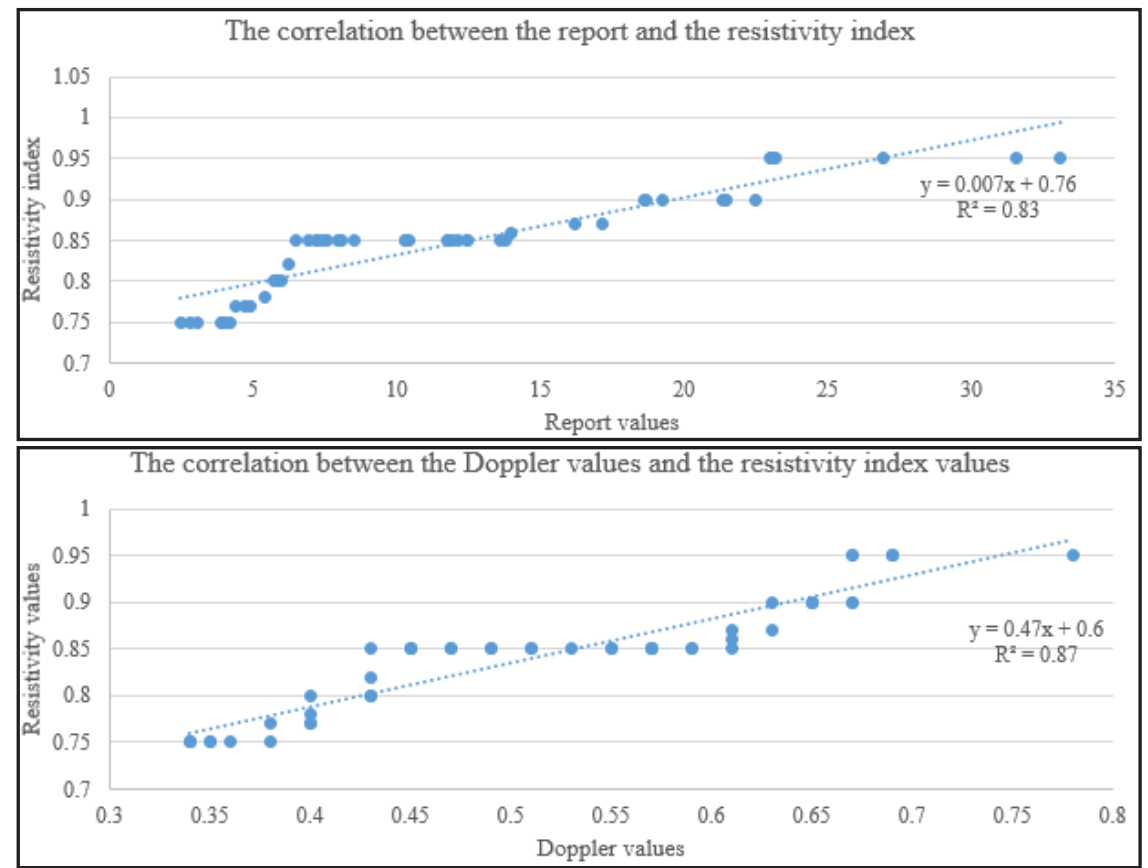

Fig. 3 The association between the report values and the resistivity index values.

Fig. 4 The association between the Doppler values and the resistivity index values
For this, we calculated the Pearson coefficient and we applied a regression model in both scenarios. In both cases we obtained a very strong positive correlation $(r=0.91$, $r_{2}=0.93$ ). The determination coefficients are $R_{1}=0.83$ and $\mathrm{R}_{2}=0.87$ and for the significance we obtained a $p<0.001$, which will conduce as to the conclusion that the observed association is extremely significant. This associations are plotted in figures 3,4 .

\section{Conclusions}

After applying the statistical tests we can say that we have a very strong positive association between the sFIt- 1 , PIGF values and the IR values and between the Doppler and the IR values in week 21 .

Pregnancy is a physiological condition for women, and the percentage of physical activity decreases. During this period, lifestyle changes in general and often tends to change over time. The progressive accumulation of chronic metabolic diseases and cardiovascular disease is usually inevitable.

More and more studies raise the theory of arterial stiffness resulting from a degenerative process that primarily affects the extracellular matrix of elastic arteries under the effect of aging. The properties of arterial elasticity are increasingly used to stratify the risk in many populations, and recently ESH / ESC recommends pulse rate (PWV) for the monitoring of high blood pressure, which is considered a gold standard for assessing arterial stiffness [21-27]. In our study, as well, we found a significant connection between the BMI and the appearance of preeclampsia. A high $\mathrm{BMI}$ value can increase the chance of developing preeclampsia during pregnancy.

\section{References}

1.PETRE, I., BERNAD, E., CRAINA, M., CITU, C., BOLINTINEANU, B., POP, E., STOIAN, D., SIPOS, S., LUNGEANU, D., FURAU, C., FURAU, Gh, PANTEA, S., IONITA, I., Determining markers PIGF, sFItl and the ratio sFIt1/PIGF - prognostic tool in patiente with preeclampsia, Rev. Chim.(Bucharest), 67, no 11, 2016, p. 2365-2369

2.IVAN, M.V., PETRE, I., VLAICU, B., APOSTOL, A., TESLOIANU, D., MUNTEANU, M., COSTACHESCU, R., MOLERIU, L.C., LAZAR, F.,The Use of Pulse Wave Velocity in Predicting Pre-Eclampsia in High-Risk Women Rev. Chim. (Bucharest), 69, no. 5, 2018, p. 1260-1263
3.MLADIN-MICOARA N,C., LUNGEANU, D., MORARIU, S.I., CIACLI ,C.A., MOLERIU, L.C, STELEA, L., PETRE, I., IONITA, I., CALAMAR-POPOVICI, D., PUSCHITA, M. - Biomarkers in Diagnosing Preeclampsia and their Correlation with Blood Pressure, Rev. Chim. (Bucharest), 68, no. 10, 2017, p. 2449-2501

4.TOTH G., ANASTASIU D., CRAINA M., CIRLOGEA A., MOLERIU R.D., CITU I., CITU C., IONITA I., PETRE I., - First Trimester Screening for Preeclampsia, The 13th Conference of the Romanian-German Society of Obstetrics and Gynecology, Timisoara, Romania, 14-16 September 2017, pg 304 - 309, Ed. Filodiritto Editore Proceeding, ISBN 978-8895922-95-9

5.TOTH G., PETRE I., CRAINA M., MOLERIU R.D., BOGLUT A., IACOB D., IONITA I., MILOICOV O., BACEAN C., Paraclinical Correlations and the Macroscopic Aspect of Placenta in Cases of HTAIS Diagnosis, 5th Congress Of The Romanian Society Of Ultrasound In Obstetrics And Gynecology, Filodiritto Editore Proceeding, Targu Mures, Romania, 20-22 April 2017, pg 482 - 486, ISBN 978-88-95922-88-1

6.VERLOHREN S., HERRAIZ I., LAPAIRE 0., et al. - The sFIt-1/PIGF ratio in different types of hypertensive pregnancy disorders and its prognostic potential in preeclamptic patients. Am J Obstet Gynecol 2012;206: e1-8 19.

7.VILLA P.M., HAMALAINEN E., MAKI A., et al. - Vasoactive agents for the prediction of early- and late-onset preeclampsia in a high-risk cohort. BMC Pregnancy Childbirth 2013; 13:110-110

8.RANA S., POWE C.E., SALAHUDDIN S., et al. - Angiogenic factors and the risk of adverse outcomes in women with suspected preeclampsia. Circulation 2012; 125:911-919.

9.HOLMES V.A., YOUNG I.S., PATTERSON C.C., et al. - The role of angiogenic and antiangiogenic factors in the second trimester in the prediction of preeclampsia in pregnant women with type 1 diabetes. Diabetes Care 2013; 36:3671-3677

10.CHAIWORAPONGSA T., ROMERO R., KORZENIEWSKI S.J., et al. Plasma concentrations of angiogenic/anti-angiogenic factors have prognostic value in women presenting with suspected preeclampsia to the obstetrical triage area: a prospective study. J Matern Fetal Neonatal Med 2014; 27:132-144

11.MOORE A.G., YOUNG H., KELLERJ .M., etal. Angiogenic biomarkers for prediction of maternal and neonatal complications in suspected preeclampsia. J Matern Fetal Neonatal Med 2012; 25:2651-2657.

12.MOZA, A., PETRE,I., PANTEA, S. - The Management of Pregnancy with Hereditary Angioedema, The 13th Conference of the RomanianGerman Society of Obstetrics and Gynecology,Timi-oara, Romania, 14-16 Sept. 2017, pag 184 -188, Ed. Filodiritto Editore Proceeding, ISBN 978-88-95922-95-9 
13.MOZA A., PETRE I., ILINA R., PANTEA S. - The Management of Pregnancy with Vasa Previa, The 13th Conference of the RomanianGerman Society of Obstetrics and Gynecology,Timi-oara, Romania, 14-16 Sept. 2017, pag 189 -193, Ed. Filodiritto Editore Proceeding,ISBN 978-88-95922-959

14.LU F.X., LONGO M., TAMAYO E., et al., The effect of over-expression of sFlt-1 on blood pressure and the occurrence of other manifestations of preeclampsia in unrestrained conscious pregnant mice. Am J Obstet Gynecol 2007; 196:396.e1-396.e7

15.VATTEN L.J ., ESKILD A., NILSEN T., JEANSSON S., J ENUM P.A., STAFF

A.C.. Changes in circulating level of angiogenic factors from the first to second trimester as predictors of preeclampsia. Am J Obstet Gynecol 2007;196:e1-e6

16.LEVINE R.J ., MAYNARD S.E., QIAN C., et al. - Circulating angiogenic factors and the risk of preeclampsia. N Engl J Med 2004;350:672-683. 17.STAFF A.C., BENTON S.J ., von DADELSZEN P., et al. - Redefining preeclampsiausing placenta-derived biomarkers . Hypertension 2013;61:932-942

18.CHAIW ORAPONGSA T., CHAEMSAITHONG P., YEO L., ROMERO R. Pre-eclampsia. Part 1. Current understanding of its pathophysiology. Nat Rev Nephrol 2014;10:466-480

19.AUGER N., FRASER W.D., PARADIS G., PROFITOS G.H., HSIEH A., RHÉAUME A.M. - Preeclampsia and Long-term Risk of Maternal Retinal Disorders. Obstetrics \& Gynecology, 2017; 129 (1): 42

$20{ }^{* * *}$ American Academy of Ophthalmology (AAO). - Does preeclampsia during pregnancy increase risk to mothers' eyes?." ScienceDaily. ScienceDaily, 1 March 2017.

21.IURCIUC S., AVRAM C., TURI V., MILITARU A., AVRAM A., CIMPEAN, A.M., IURCIUC M. - Physical Training, Hemodynamic Parameters and Arterial Stiffness: Friends or Foes of the Hypertensive Patient. View Researcher ID and ORCID IN VIVO Volume: 30 Issue:4, Pages: 521-528, 2016.
22.IURCIUC S.; CIMPEAN, AM ; MITU, F; HEREDEA, R; IURCIUC, M. Vascular aging and subclinical atherosclerosis: why such a "never ending" and challenging story in cardiology? CLINICAL INTERVENTIONS IN AGING, Volume: 12 Pages: 13391345 DOI: $10.2147 / C I A . S 141265,2017$

23.IURCIUC S; VLAD A., IURCIUC M., AVRAM A., CIORACA G., AVRAM C., CRACIUN L., URSONIU S., GAITA D, etall., - Risk factor and lifestyle changes in high risk patients. JOURNAL OF HYPERTENSION, Volume: 28. Pages: E377-E378, Meeting Abstract 20th Annual Meeting of the European-Society-of-Hypertension. Oslo, Norway. 2010,

24.IURCIUC M., AVRAM C., IURCIUC S., FRANCULESCU C., VLAD A., MANCAS, S., - Comprehensive rehabilitation programs may improve some of the ambulatory blood pressure parameter., XXXVIII SIMFER National Congress, 1TTH ESPRM EUROPEAN CONGRESSOF PHYSICAL AND REHABILITATION MEDICINE. Pages: 253, Venice, Italy 2010. 25.IURCIUC M., GAITA D., IURCIUC S., AVRAM C., DUDA-SEIMAN D., CIORICA, G., COBZARIU, I.F., ORAVITAN M., URSONIU S. - The importance of arterial stiffness in a rehabilitation program at hypertensive person. JOURNAL OF HYPERTENSION, Volume: 27, Pages: S287-S288, Conference: 19th European Meeting on Hypertension, Milan, Italy 2009.

26.IURCIUC M., GAITA D., IURCIUC S., AVRAM C., FIRA-MLADINESCU 0., ORAVITAN M., MANCAS S. - The evolution of arterial stiffness and hemodynamic parameters following an rehabilitation program. J OURNAL OF HYPERTENSION, Volume: 26. Pages: S492-S492. Conference: 18th Scientific Meeting of the European-Society-ofHypertension/22nd Scientific Meeting of the International-Society-ofHypertension, Berlin, Germany, 2008.

27.IURCIUC M., GAITA D., IURCIUC S., DRAGAN S., DUDA-SEIMAN D., DUMITRASCIUC M., AVRAM A., MANCAS S., - The benefit of exercise training on arterial stiffness at hypertensive patients. EUROPEAN HEART J OURNAL, Volume: 28. Pages: 523-523. Meeting Abstract 2007

Manuscript received:21.08.2018 